\begin{tabular}{l}
\hline sciendo $\frac{\text { ECONOMIC THEMES (2021) 59(2): 259-280 }}{\text { DOI } 10.2478 / \text { ethemes-2021-0015 }}$ \\
\hline
\end{tabular}

\title{
STATISTICAL ANALYSIS OF INTERDEPENDENCE OF ICT AND ECONOMIC DEVELOPMENT OF SELECTED EUROPEAN COUNTRIES
}

\author{
Milan Stamenković \\ University of Kragujevac, Faculty of Economics, Republic of Serbia \\ $\bowtie$ m.stamenkovic@kg.ac.rs \\ Marina Milanović \\ University of Kragujevac, Faculty of Economics, Republic of Serbia \\ $\square$ milanovicm@kg.ac.rs \\ Dragana Rejman Petrović \\ University of Kragujevac, Faculty of Economics, Republic of Serbia \\ $\triangle$ rejman@kg.ac.rs
}

UDC

519.23

004:330.34

Original

scientific

paper

Received:

12.02.2021

Accepted:

28.02.2021
Abstract: The research focus on the analysis of interdependence of economic and ICT development results from the fact that, in recent decades, ICTs have become a dominant factor in generating socio-economic prosperity of countries. ICT expansion is a stimulus for economic growth, and vice versa. In order to empirically verify the observed interdependence, on the example of the selected 37 European countries, a two-stage statistical analysis was conducted, based on a combined application of cluster analysis and a oneway analysis of variance. Using specific data from 2017, the following was conducted: (a) formation of groups of countries by implementing cluster analysis based on the three structural components of the ICT Development Index; and (b) by applying the ANOVA method and using the values of GDP per capita, testing the validity of assumption regarding the existence of statistically significant differences, in terms of the achieved level of economic development between the formed groups of countries of different levels of ICT development. The obtained results suggest the extraction of three clusters of countries and the acceptance of the defined hypothesis. Serbia is classified within the cluster of medium ICT development level and is characterized by the value of GDP per capita that is significantly below the group average, which indicates the possibility and the need for improvement in the ICT field.

Keywords: statistical analysis, cluster analysis, ANOVA, ICT development, economic development, selected European countries

JEL classification: C38, C12, O33, O47, O57 


\section{Introduction}

In recent decades, the (r)evolution of information and communication technologies and knowledge, together with the pronounced globalization of business and activities of economic entities has resulted in significant opportunities in the field of increasing national wealth and social welfare (Hogan, 2011). In the modern economic environment, raising the competitiveness of the national economy and providing conditions for sustainable economic development is directly conditioned by the potential and ability of economic entities (and, thus, the economy as a whole) to develop and expand new and efficiently exploit the existing knowledge (Krstić \& Džunić, 2013). "Identifying" knowledge, education, information and innovation as the key drivers of economic growth and, consequently, positioning the activities of sustainable use and the creation of knowledge at the centre of the process of ensuring long-term economic development has conditioned the transition of world economy to a knowledge-based economy.

In order to accelerate and increase the efficiency of this transition process at the global level, the World Bank Institute, within the Knowledge for Development (K4D) Program, has developed a Knowledge Assessment Methodology (KAM) that represents an interactive diagnostic and benchmarking tool, designed to provide a basic assessment of the readiness of individual economies and / or regions to transition to the knowledge economy, based on the achieved construction level of the following four pillars of the knowledge economy: (I) establishing a supportive economic environment and institutional regime, (II) raising the level of education and skills of the workforce, (III) developing an efficient innovation system, and (IV) developing and using modern information and communication technology and infrastructure (World Bank Institute, 2008).

While respecting the unequivocal importance of each individual pillar, as well as their interconnectedness and causality, it is important to emphasize the dominant position and role that modern information and communication technologies and infrastructure have in terms of creating a basis for the development of this new economy. In fact, the rapid progress and strides made in recent decades in the field of information and communication technology development (ICT), have significantly contributed to reducing the costs of expanding ICT infrastructure and its use, thus creating the necessary basis (based on the possibilities of electronic networking and connecting researchers from different scientific fields in different geographical locations) for efficient dissemination of existing knowledge, but also notable progress in research and development (creation) of new knowledge, ideas and technologies (Statistics Netherlands, 2015). In other words, one of the most obvious benefits related to the use of ICT is reflected in the increased flow of information and knowledge, because it enables easier procurement and adaptation of technologies, which further leads to the resulting increase in innovation and productivity. 
In general, ICTs are the backbone of the knowledge economy, and their development and widespread use in order to increase the productivity of traditional factors of production is a prerequisite for achieving economic growth and longterm development (Chen \& Dahlman, 2006). Accordingly, it is not surprising that the investigation of relations between the level of ICT and economic development at the level of individual and / or selected groups of countries represents an attractive research niche among the representatives of the scientific community.

Consequently, the examination of the interrelationship between the degree of ICT development and the degree of economic development of selected European countries, based on a specific combination of multivariate and univariate methods of statistical analysis, is the subject of research in this paper. In the context of the defined subject, the following research objectives have been formulated: (1) the presentation of application possibilities of cluster analysis method in the domain of defined subject, through independent and combined use with the appropriate univariate statistical methods; (2) the classification of observed European countries into appropriate, internally homogeneous / externally heterogeneous groups, according to selected indicators of ICT infrastructure development; (3) the analysis of differences in terms of achieved level of economic development of countries in different clusters, formed in the context of previously performed classification, based on testing the validity of the following research hypothesis: there is a statistically significant difference in terms of the achieved level of economic development between the clusters of countries, formed according to the achieved level of ICT development; and (4) the analysis of the position of Serbia in the formed classification, according to the achieved level of ICT development.

Accordingly, the paper is structured as follows. After certain introductory remarks related to the subject of the research, Section 2 presents a brief summary of the literature review of the subject, including the conceptual framework of the IDI index, as a composite indicator of ICT development level. Section 3 includes the methodological framework of the research, while the next section contains a description of the variables, citation of sources and definition of the spatial-temporal coverage of the data. The obtained results of the applied methodology are presented in Section 4, and their interpretation within Section 5. Finally, brief concluding remarks on the key results of the conducted empirical research are made.

\section{Research background}

In recent decades, the widely acceptance of ICTs as a catalyst, driver and dominant factor in generating economic and social prosperity of developed and developing countries has led to the publication of a series of studies examining interdependence and relations between the development and application of ICT and economic growth and development of individual countries and economic regions. ICTs can be regarded as a result of economic growth, and vice versa. Essentially, 
the dynamics of economic growth is one of the most important factors influencing the development of the ICT industry (Mitrović \& Manić, 2019), while, at the same time, the expansion of the ICT sector is a stimulus for economic growth. In the analysis of the complexity of this relationship, most authors conclude that ICTs can be considered a consequence and one of the causes of economic growth (Stankić et al., 2018), i.e. there is a causal relationship between these phenomena.

In general, most of the studies confirm the presence of a direct quantitative agreement between the variations of the considered ICT indicators and indicators of economic growth and development of the analyzed geographical units of observation. Also, by many international organizations, the ICT sector has been identified as a key factor of sustainable development. Observed from the methodological angle and applied statistical methods, it is interesting to point out that the conclusions are mainly the result of causality analysis and multiple regression analysis of panel data.

Bearing in mind the identified pronounced variability of the content of these empirical studies, which is manifested in the context of:

- spatial coverage of data (for example, developed countries, developing countries, countries on individual continents, selected countries of different continents, regions, etc.),

- analyzed time period and / or moment,

- implemented statistical methodologies, data sources, variables used as "representative" indicators of the observed phenomena,

- research objectives (for example, examination of the direction and degree of correlation, statistical significance of the impact of ICT indicators on economic growth and development indicators, examination of causality between considered phenomena, classification of observation units, etc.), and finally,

- obtained results and derived conclusions for gaining insight into the state of considered issues, interested readers are referred to detailed reviews of previous research, contained in the following papers: Souter (2004), Van Reenen et al. (2010), Farhadi et al. (2012), Biagi (2013), Niebel (2014), Mefteh \& Benhassen (2015), Toader et al. (2018), Majeed \& Ayub (2018), Vu et al. (2020), Aly (2020).

Starting from the identified similarities with the formulated research objectives, spatial data coverage and multivariate methodological framework in this paper, the research conducted by Zoroja \& Pejić-Bach (2016) stands out. More precisely, unlike most other studies, these authors conducted a two-stage analysis, based on the combined application of non-hierarchical cluster analysis and one-factor ANOVA procedure, in order to examine the individual impact of four composite ICT components (as indicators of ICT development) on competitiveness and economic development of selected European countries in 2011. Similarly, Guzel et al. (2016) use a hierarchical agglomerative procedure of cluster analysis on data from 2013, in order to determine the position of Turkey in relation to the selected 22 developing 
countries, in terms of the achieved level of economic and ICT development. Using the Kohonen Self-Organizing Map (the SOM algorithm) to group the observed countries, Soldić-Aleksić \& Stankić (2016) analyze the position of Serbia and its 'distance' from the EU member states in the domain of Networked Readiness Index, using the values of 54 indicators in 2014, as the measure of a country's readiness to seize the opportunities offered by ICT. The so-called BRICS countries, with their technological potential and growing importance in the global economy, inspired Görkey Aydınoğlu \& Yalk Berker (2016) to examine their economies from the perspective of ICT development and determine the position of each BRICS country relative to 200 countries during the period from 2005 to 2013, including the evaluation of the performance of each versus the other BRICS. For these purposes, cluster analysis was applied, using the following variables, i.e. ICT proxies for defining groups: fixed broadband subscriptions, fixed-telephone and mobile-cellular telephone subscriptions, and the percentage of individuals using the Internet.

It follows from the above stated that the ranking and classification of territorial units into appropriate groups according to development indicators is often an integral part of research studies that address the issue of interdependence of levels of economic and ICT development. However, the direct comparison of the results of the conducted studies is significantly difficult due to the already mentioned, pronounced variability in the context of the key segments of the analysis, including the difference related to the used indicators of ICT development.

Table 1: Structure of the composite ICT Development Index

\begin{tabular}{|c|c|c|c|c|}
\hline Index & Sub-indices & & Individual indicators & Weights \\
\hline \multirow{11}{*}{$\begin{array}{c}\text { ICT } \\
\text { Development } \\
\text { Index } \\
\text { (IDI) }\end{array}$} & \multirow{5}{*}{ ICT Access } & 1. & $\begin{array}{l}\text { Fixed-telephone subscriptions } \\
\text { per } 100 \text { inhabitants }\end{array}$ & \multirow{5}{*}{$40 \%$} \\
\hline & & 2. & $\begin{array}{l}\text { Mobile-telephone subscriptions } \\
\text { per } 100 \text { inhabitants }\end{array}$ & \\
\hline & & 3. & $\begin{array}{l}\text { International internet bandwidth } \\
\text { (bit/s) per internet user }\end{array}$ & \\
\hline & & 4. & $\begin{array}{l}\text { Percentage of households with } \\
\text { a computer }\end{array}$ & \\
\hline & & 5. & $\begin{array}{l}\text { Percentage of households with } \\
\text { internet access }\end{array}$ & \\
\hline & \multirow{3}{*}{ ICT Use } & 6. & $\begin{array}{l}\text { Percentage of individuals using } \\
\text { the internet }\end{array}$ & \multirow{3}{*}{$40 \%$} \\
\hline & & 7. & $\begin{array}{l}\text { Fixed-broadband subscriptions } \\
\text { per } 100 \text { inhabitants }\end{array}$ & \\
\hline & & 8. & $\begin{array}{l}\text { Active mobile-broadband } \\
\text { subscriptions per } 100 \text { inhabitants }\end{array}$ & \\
\hline & \multirow{3}{*}{ ICT Skills } & 9. & Mean years of schooling & \multirow{3}{*}{$20 \%$} \\
\hline & & 10. & Secondary gross enrolment ratio & \\
\hline & & 11. & Tertiary gross enrolment ratio & \\
\hline
\end{tabular}

Source: ITU (2009) 
Based on the previous discussion, the following questions arise: How is ICT development measured from different perspectives? How to evaluate countries' ICT development levels for the purpose of their comparison? The research conducted by reference institutions and teams of researchers in function of finding answers to these questions has resulted in creation of a multitude of composite indicators for measurement and comparison of countries' informational development. In fact, instead of using a set of individual indicators, the specific aspects of ICT development have been incorporated into composite ICT indices created over the last few decades, such as: Digital Access Index (DAI), Digital Opportunity Index (DOI), ICT Opportunity Index (ICTOI), ICT Development Index (IDI), Networked Readiness Index (NRI), Digital Economy and Society Index (DESI). In accordance with the defined research objectives, in this paper, the ICT Development Index (IDI), whose conceptual framework is presented in Table 1, is used.

The specified index was created by the International Telecommunication Union (ITU), in response to requests from ITU members to incorporate numerous and diverse ICT indicators into a single composite index suitable for monitoring the digital divide and the achieved level of information society development (ITU, 2009). In fact, IDI is a benchmarking statistical tool that combines 11 indicators into one measure suitable for monitoring and comparing the levels and potential of ICT developments between countries, including evolution over time. (All relevant information on current debates and discussions regarding the expansion of the structure of this index and the challenges related to the quality and quantity of data is publicly available and can be accessed at $h t t p: / / w w w . i t u . i n t$.

\section{Research methodology framework}

The realization of defined research goals is based on the combined application of cluster analysis (CA), as the most frequently used method of multivariate statistical analysis and one-factor analysis of variance (i.e. one-way ANOVA), as a univariate parametric statistical method. A schematic presentation of the used research methodology framework, complemented by detailed explanations of implemented statistical methods and their key determinants, is given in Figure 1.

Cluster analysis is a multivariate statistical method designed for the detection of a "hidden" structure in a set of multivariate observations through the classification of individual observation units into a certain, mainly previously unknown, number of clusters (i.e. groups), based on determined similarities or differences between them, in terms of the values of carefully selected variables (Đorđević et al., 2011). Based on the selection of appropriate distance measure and the application of a particular clustering procedure (hierarchical and/or non-hierarchical), cluster analysis enables the allocation of $n$ observation units into $k$ mutually independent and exclusive clusters $C_{g}$, (for $\left.g=1,2, \ldots, k\right)$, where $k<<n$, but in such a way that units within the same cluster are very similar to each other, and vice versa. 
Figure 1: Schematic representation of the research methodology framework

\begin{tabular}{|c|c|c|}
\hline $\begin{array}{l}\text { SELECTION of ICT indicators } \\
\qquad\left[\mathrm{X}_{1}, \mathrm{X}_{2}, \mathrm{X}_{3}\right]\end{array}$ & $\downarrow$ CLUSTH & JALYSIS \\
\hline$\downarrow$ & \multirow{2}{*}{$\begin{array}{l}\text { Hierarchical methods: } \\
\text { - Complete-linkage } \\
\text { - Average-linkage } \\
\text { - Ward's method }\end{array}$} & \multirow{2}{*}{$\begin{array}{l}\text { Selection of the } \\
\text { optimal method using } \\
\text { cophenetic correlation } \\
\text { coefficient }\end{array}$} \\
\hline \multirow{3}{*}{$\begin{array}{l}\text { PRELIMINARY ANALYSIS: } \\
\text { - Descriptive statistics } \\
\text { - Outlier analysis } \\
\text { (univariate \& multivariate) }\end{array}$} & & \\
\hline & & $\downarrow$ \\
\hline & & Dendrogram \\
\hline \multirow{3}{*}{$\begin{array}{l}\text { One-way ANOVA: } \\
\text { - Level of ICT development } \\
\text { (independent variable) } \\
\text { - GDP per capita } \\
\text { (dependent variable) }\end{array}$} & \multirow{3}{*}{$\begin{array}{l}\text { Quality evaluation of } \\
\text { selected clustering } \\
\text { solution using } \\
\text { silhouette coefficient }\end{array}$} & $\downarrow$ \\
\hline & & $\begin{array}{l}\text { Selection of the } \\
\text { clustering solution }\end{array}$ \\
\hline & & optimality criterion \\
\hline
\end{tabular}

Source: Authors' representation

The process of creating a statistically valid classification of selected European countries into appropriate groups according to the achieved level of ICT development, based on an adequate preliminary data analysis, is characterized by the following main methodological determinants:

- Examination of the presence of univariate and multivariate outliers based on box-plot diagrams and values of the Mahalanobis distance measure calculated for individual multivariate observations, respectively;

- Implementation of a most suitable hierarchical agglomerative clustering method, selected based on the values of cophenetic correlation coefficient, and the squared Euclidean distance as a measure of distance between observation units.

- The selection of the "optimal" clustering solution, regarding the number of formed groups, was performed by analyzing variations in the increment of distance measure values between groups during the iterative process of conducted hierarchical agglomeration.

- A comprehensive evaluation of the quality of selected clustering solution was conducted using the silhouette coefficient (Rousseeuw, 1987).

After the described classification, in order to test the hypothesis regarding the existence of statistically significant differences between the average values of GDP per capita within the identified groups of countries with different levels of ICT development, a one-way ANOVA was conducted. A valid implementation of ANOVA method is ensured by a detailed verification of fulfilment of statistical assumptions (i.e. independence of observations and univariate normality by formed clusters, as well as the homogeneity of population variances) on which it is based. The analysis of collected data and all necessary statistical calculations were performed using statistical software packages IBM-SPSS Statistics version 20.0 and 
EduStat 4.05. The final interpretation of the analysis results is complemented by adequate tabular, graphical and cartographic representations.

\subsection{Variables, sources and spatial-temporal scope of data}

For the purpose of effective realization of formulated research objectives, secondary data of the following numerical variables were collected: (a) for the classification of the analyzed observation units according to the level of achieved ICT development, data from three main sub-indices of the IDI composite indicator, particularly ICT Access sub-index, ICT Use sub-index and ICT Skills sub-index, were used [data source: electronic database of the International Telecommunication Union (http://www.itu.int)]; and (b) for the examination of interdependence between the identified levels of ICT development and the degree of economic development, data for variable Gross Domestic Product per capita according to purchasing power parity in US dollars (i.e. GDP per capita, PPP US \$) were collected, [data source: International Monetary Fund electronic database (http://www.imf.org)]. The data obtained for all variables refer to year 2017. The spatial scope of the research covers the following 37 selected countries in Europe: EU-28 member states (Austria [AUT], Belgium [BEL], Bulgaria [BGR], United Kingdom [GBR], Greece [GRE], Denmark [DNK], Estonia [EST], Ireland [IRL], Italy [ITA], Cyprus [CYP], Lithuania [LTU], Latvia [LVA], Luxembourg [LUX], Hungary [HUN], Malta [MLT], Germany [GER], Poland [POL], Portugal [POR], Romania [ROU], Slovenia [SVN], Slovakia [SVK], Finland [FIN], France [FRA], Netherlands [NLD], Croatia [CRO], Czech Republic [CZE], Spain [ESP], Sweden [SWE] ), candidate countries and potential candidates for EU membership (Serbia [SRB], Montenegro [MNE], Northern Macedonia [MKD], Bosnia and Herzegovina $[\mathrm{BIH}]$, Albania $[\mathrm{ALB}]$ and Turkey [TUR]) and selected countries that are not part of EU by their own decision (Iceland [ISL], Norway [NOR], Switzerland [CHE]).

\section{Empirical research}

In accordance with the presented two-stage methodological framework, as already stated, on selected sub-indices of the ICT Development Index, a cluster analysis was conducted in order to classify analyzed European countries into internally homogeneous and externally heterogeneous clusters according to the achieved level of development of information and communication technologies. Since the values of the used ICT indicators, as constituent components of the IDI composite index, are the result of aggregation of normalized and weighted values of carefully selected original indicators that make up their structure (Table 1), they are expressed in index points varying from 1 to 10 , due to which the procedure of additional normalization was not carried out. In Table 2, the values of arithmetic means $(\bar{x})$, medians $\left(m_{e}\right)$, standard deviations $(s)$, coefficients of variation $(c v)$, as well as maximum (max) and minimum ( $\mathrm{min}$ ) values for the used ICT sub-indices are presented. 
Table 2: Descriptive statistical measures of selected ICT development indicators

\begin{tabular}{|l|c|c|c|c|c|c|c||}
\hline \hline \multicolumn{2}{|c|}{ IDI sub-indices } & $\bar{x}$ & $m_{\mathrm{e}}$ & $\min$ & $\max$ & $s$ & $c v$ \\
\hline ICT Access & $X_{1}$ & 7.77 & 7.86 & $4.80[\mathrm{ALB}]$ & $9.54[\mathrm{LUX}]$ & 0.99 & $12.72 \%$ \\
\hline ICT Use & $X_{2}$ & 6.90 & 6.67 & $4.42[\mathrm{ALB}]$ & $8.94[\mathrm{DNK}]$ & 1.29 & $18.70 \%$ \\
\hline ICT Skills & $X_{3}$ & 8.01 & 8.17 & $6.03[\mathrm{MKD}]$ & $9.00[\mathrm{GRE}]$ & 0.72 & $8.99 \%$ \\
\hline
\end{tabular}

Source: Authors' calculations (IBM SPSS Statistics 20.0)

Within the preliminary analysis and data preparation, the possible presence of one-dimensional and multivariate non-standard observations was examined, using graphical representations in the form of individual box-plots and values of the Mahalanobis distance measure, respectively. More precisely, presented graphical representations for individual indicators (Figure 2) and approximate values of positional and calculated measures of central tendency confirm the absence of onedimensional outliers, with $[\mathrm{ALB}]$ and $[\mathrm{MKD}]$ marked only as moderate (i.e. suspected) non-standard observations in the case of indicators $X_{1}$ and $X_{3}$, respectively. In addition, the lowest variability between the analyzed countries is recorded for variable $X_{3}$, while the highest values of displayed dispersion measures $(s$ and $c v)$ are present in the case of variable $X_{2}$.

Figure 2: Box-plots for individual indicators of ICT development

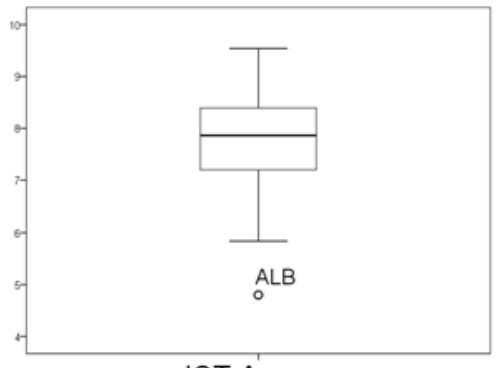

ICT Access

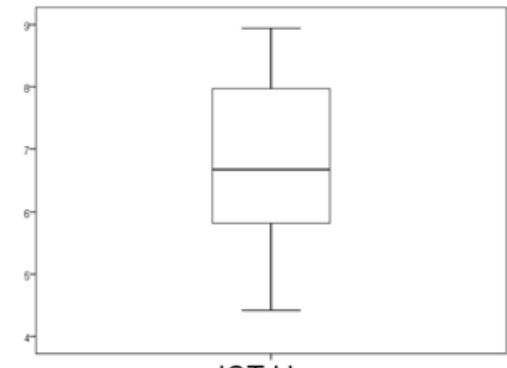

ICT Use

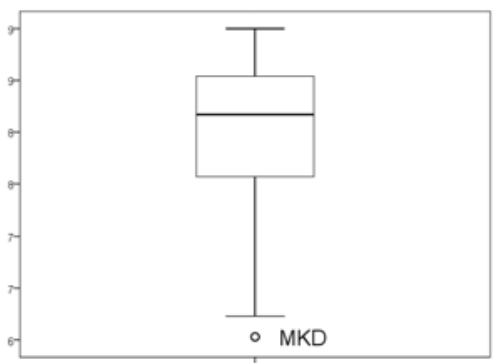

ICT Skills

Source: Authors' representation (IBM SPSS Statistics 20.0) 
On the other hand, since $[\mathrm{ALB}]$ and [LUX] are characterized by the values of Mahalanobis distance measure (particularly, 10.063 and 10.800 , respectively) which are above the defined critical value of chi-square distribution, $\chi_{(3 ; 0.975)}^{2}=$ 9.348 , the presence of two multivariate outliers can be noted and confirmed. However, since these two multidimensional observations represent an important, though small, part of the analyzed set of European countries, which contains very useful information for comparing and creating an objective map of the state of ICT development in Europe, their complete exclusion from further analysis has not been performed, although special attention will be paid to their positioning and allocation during the clustering process.

For the purpose of selecting the most suitable approach for the classification of observed countries, on pre-processed multivariate observations, using the squared Euclidean distance as an appropriate distance measure, the results of the most commonly used hierarchical agglomerative clustering methods were obtained and compared. By comparing the values of cophenetic correlation coefficient calculated for the results of different clustering methods (Table 3), the solution of clustering problem obtained by implementation of average-linkage method was singled out as the most interpretable and of the highest quality, since it is characterized by the highest $r_{c p}$ value.

Table 3: Cophenetic correlation coefficient values for different clustering methods

\begin{tabular}{|c|c|}
\hline \hline Hierarchical clustering methods & Cophenetic correlation coefficient $\left(r_{c p}\right)$ \\
\hline Complete-linkage method & 0,542 \\
\hline Average-linkage method & $\mathbf{0 . 6 9 8}$ \\
\hline Ward's method & 0.544 \\
\hline
\end{tabular}

Source: Authors' calculations (IBM SPSS Statistics 20.0)

The summary results of hierarchical (average-linkage) agglomerative clustering of 37 European countries, according to the values of selected ICT development indicators, are presented in the form of dendrogram (Figure 3).

However, since the goal of CA is not to develop a complete hierarchical tree, but to identify and single out "natural" internally homogeneous and externally heterogeneous clusters of countries according to the observed indicators, the selection of the "optimal" number of clusters was made on the basis of appropriate optimality criterion, as presented in methodology framework. Accordingly, graphical representation of the increment (i.e. absolute changes) of distance measure values between countries and / or groups of countries in successive steps of agglomeration process is presented in Figure 4. 
Figure 3: Dendrogram

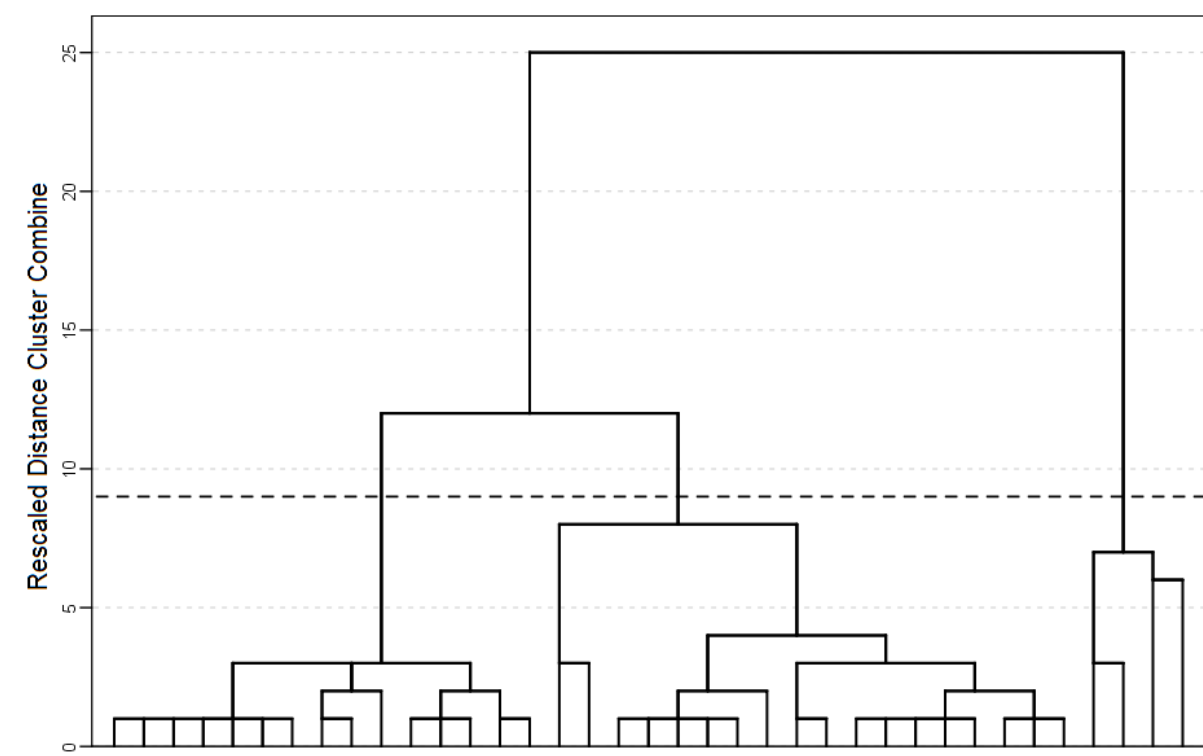

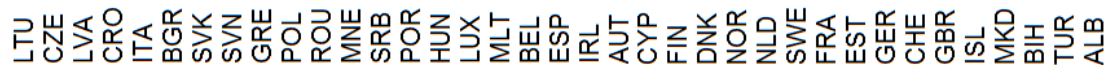

Source: Authors' representation (IBM SPSS Statistics 20.0)

Figure 4: Graphical representation of distance measure values' absolute changes during the agglomeration process

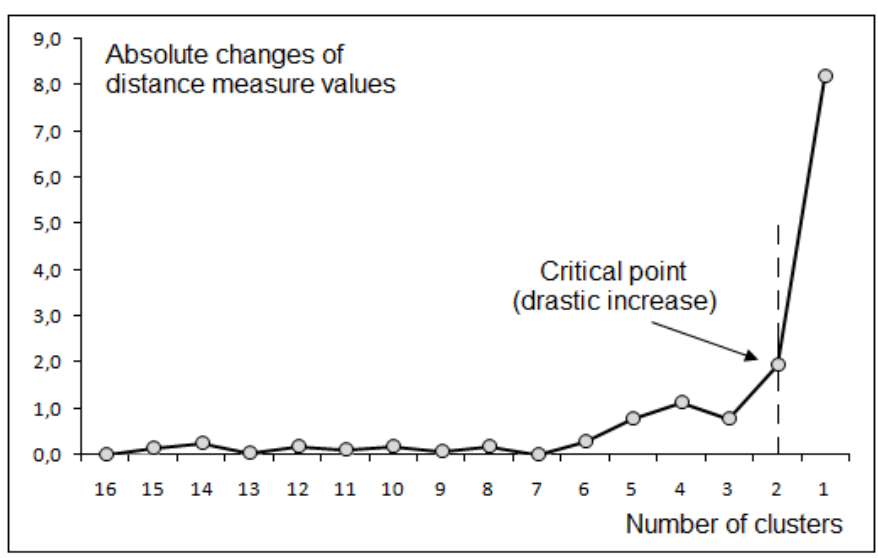

Source: Authors' representation

Graphical representation, created for solutions ranging from 16 to 1 cluster, clearly reveals a sudden break of a continuous and gradual, slight increase of 
absolute changes of distance measure values between groups, which occurred in $35^{\text {th }}$ step of the iterative process of agglomeration, that is, at the time of forming a solution that includes two clusters. Since the observed drastic change in variation of the increment values occurred as a result of merging highly heterogeneous groups, the number of clusters formed in a preceding step, i.e. the classification that includes three clusters of countries, is chosen to be the "optimal" solution. Graphical confirmation of justification of selected classification of analyzed countries into three groups is given in Figure 5 and the distribution of individual countries by extracted clusters in Table 4 .

Table 4: Classification of countries by formed three clusters

\begin{tabular}{|c|c|c|c|}
\hline \multicolumn{3}{|c|}{ Clusters } & \multirow{2}{*}{ Countries within the formed clusters } \\
\hline Code & "Description" & Size & \\
\hline 1 & $\begin{array}{l}\text { High level of } \\
\text { ICT development }\end{array}$ & 18 & $\begin{array}{l}\text { EU members: AUT, BEL, DNK, ESP, FIN, FRA, } \\
\text { GBR, GER, LUX, NLD, SWE, IRL, CYP, EST, MLT } \\
\text { Countries outside the EU: ISL, CHE, NOR }\end{array}$ \\
\hline 2 & $\begin{array}{l}\text { Medium level of } \\
\text { ICT development }\end{array}$ & 15 & $\begin{array}{l}\text { EU members: GRE, ITA, POR, BGR, LTU, LVA, } \\
\text { HUN, POL, SVN, SVK, CZE, ROU, CRO } \\
\text { EU candidates: SRB, MNE }\end{array}$ \\
\hline 3 & $\begin{array}{l}\text { Low level of } \\
\text { ICT development }\end{array}$ & 4 & $\begin{array}{l}\text { EU candidates: TUR, ALB, MKD } \\
\text { EU potential candidate: } \mathrm{BIH}\end{array}$ \\
\hline
\end{tabular}

Source: Authors' representation

Figure 5: 3D Scatter diagram of classification of European countries according to the selected indicators of ICT development

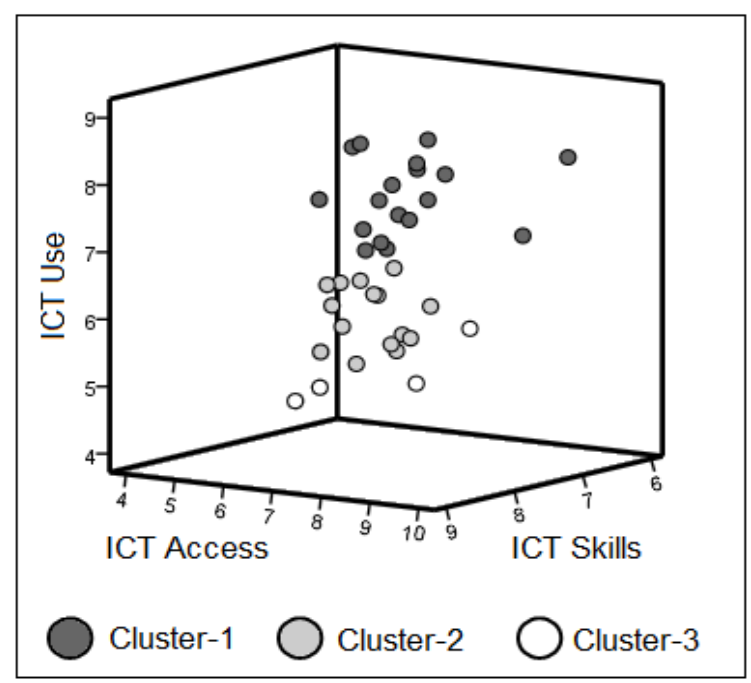

Source: Authors' representation (IBM SPSS Statistics 20.0) 
Finally, the value of silhouette coefficient (overall silh $=0.645$ ), as a statistical measure intended for a comprehensive evaluation of quality of clustering results, calculated for a solution that includes three clusters, clearly indicates that the selected cluster structure is of moderate quality, since it ranges from 0.50 to 0.70 (Izenman, 2008). Previous statement is confirmed by the silhouette coefficient values calculated for individual clusters within the structure of proposed clustering solution (Table 5). Relatively low quality of the third cluster's structure (i.e. $\operatorname{silh}_{(3)}$ $=0.399$ ) is conditioned by the fact that the observation [TUR] is characterized by a negative value of individual silhouette coefficient $\left(\operatorname{silh}_{\text {(TUR })}=-0.103 \approx 0\right)$.

Table 5: Silhouette coefficient values for extracted hierarchical clustering solution

\begin{tabular}{||c|c|c|c|c||}
\hline \multirow{2}{*}{ Coefficient } & \multicolumn{3}{|c|}{ Cluster code } & \multirow{2}{*}{ Overall solution } \\
\cline { 2 - 4 } & 1 & 2 & 3 & \\
\hline Silhouette value & 0.624 & 0.735 & 0.399 & 0.645 \\
\hline
\end{tabular}

Source: Authors' calculations

In order to examine whether there are statistically significant differences between the average values of GDP per capita within the formed clusters of European countries according to their ICT development level, one-way ANOVA was conducted. In this context, the identified level of ICT development for selected clusters of countries represents an independent (categorical) variable with three treatments (i.e., high, medium and low level of ICT development), while the GDP per capita, as a general indicator of the degree of economic development of the observed countries, represents a dependent (continuous numerical) variable. The tested alternative hypothesis claims that there is a statistically significant difference between the average values of GDP per capita of at least two clusters of countries, formed according to the achieved level of ICT development.

Table 6: The results of statistical tests for univariate distribution normality

\begin{tabular}{|c|c|c|c|c|c||}
\hline \multirow{2}{*}{$\begin{array}{c}\text { Dependent } \\
\text { variable }\end{array}$} & \multirow{2}{*}{$\begin{array}{c}\text { Categories of } \\
\left(Y_{i}\right)\end{array}$} & \multicolumn{3}{|c|}{ Anderson-Darling normality test } \\
\cline { 3 - 6 } & Independent var. & \multicolumn{2}{|c|}{37 countries } & \multicolumn{2}{|c||}{ without Luxembourg } \\
\cline { 3 - 6 } & ICT development) & AD statistic & $p$-value & AD statistic & $p$-value \\
\hline \multirow{2}{*}{$\begin{array}{c}\text { GDP } \\
\text { per capita }\end{array}$} & High level & 1.210 & 0.0027 & 0.491 & 0.1904 \\
\cline { 2 - 6 } & Medium level & 0.206 & 0.8388 & 0.206 & 0.8388 \\
\cline { 2 - 6 } & Low level & 0.453 & 0.1184 & 0.453 & 0.1184 \\
\hline
\end{tabular}

Source: Authors' calculations (EduStat 4.05)

Since ANOVA is a parametric statistical method, in order to ensure its valid implementation, the fulfilment of assumptions on which it is based was checked. Accordingly, testing the normality of dependent variable's distribution for selected 
clusters of countries was performed, using the Anderson-Darling normality test. The presented results (Table 6, columns III and IV) suggest that there is not enough empirical evidence to reject the null hypothesis regarding the normality of distribution of dependent variable in the case of Cluster-2 and Cluster-3, since the obtained $p$-values are greater than defined level of significance $\alpha=0.05$, in contrast to Cluster-1, where an alternative hypothesis was adopted.

In order to identify possible reasons for non-fulfilment of assumption regarding the distribution normality in case of Cluster-1, one-dimensional outlier analysis of dependent variable was performed using box-plot diagrams for clusters (Figure 6).

Figure 6: Box-plots of dependent variable by individual clusters of countries

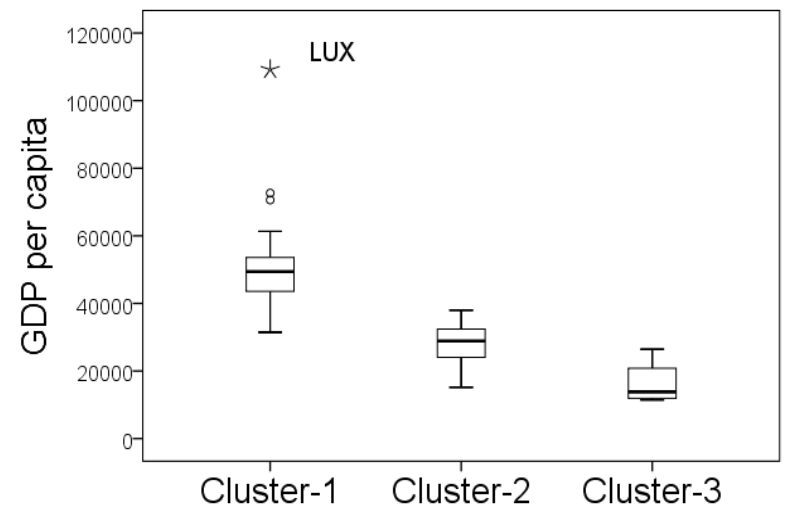

Source: Authors' representation (IBM SPSS Statistics 20.0)

The constructed box-plot for Cluster-1 clearly indicates the presence of one true atypical observation [LUX] and a couple of potential extreme values. After the elimination of Luxembourg from the group of countries with a high level of ICT development, the effects of its exclusion were checked by retesting the hypothesis about the normality of univariate distribution of variable GDP per capita for each cluster (Table 6 , columns V and VI). In addition, the assumption of homogeneity of population variance was confirmed by the results of Levene's test (test statistic $=$ 1.154 , for the degrees of freedom $\left.v_{1}=2, v_{2}=33\right)$, since the $p$-value $(0.328)$ is higher than the type I error risk $(\alpha=0.05)$.

After checking and verifying the fulfilment of all assumptions, in order to make a decision regarding the formulated statistical hypotheses, a one-factor ANOVA was performed by calculating the $F$ test statistic. As the calculated value of $F$ test statistic $(F=34.160)$, for degrees of freedom $v_{1}=2$ and $v_{2}=33$, is higher than the critical value of the test $\left(F_{(0.05 ; 2 ; 33)}=3.285\right)$, it can be concluded, with the risk of type I error $\alpha=0.05$, that there is a sufficient empirical evidence to reject $\mathrm{H}_{0}$ and adopt an alternative, claiming that there is a statistically significant difference between the average GDP per capita values of at least two of the three observed 
categories of countries determined by the level of achieved ICT development. In order to determine between which groups of countries a statistically significant difference in the dependent variable's average values exists, a multiple comparison of all possible pairs of categories of the independent variable was performed using Fisher's Least Significant Difference (LSD) post hoc test (Table 7).

The presented results suggest that European countries with a high level of ICT development, greatly differ statistically from European countries with medium and low level of ICT development, in terms of the average value of GDP per capita. An identical conclusion can be formulated when it comes to the average values of dependent variable characteristic for clusters of countries with identified medium and low levels of ICT development.

Table 7: The results of Fisher's LSD post hoc tests

\begin{tabular}{||c|c|c|c|c|c||}
\hline \hline $\begin{array}{c}\text { Independent } \\
\text { variable }\end{array}$ & $\begin{array}{c}\text { Cluster for } \\
\text { comparison }\end{array}$ & $\begin{array}{c}\text { Mean } \\
\text { difference }\end{array}$ & $\begin{array}{c}\text { LSD test } \\
\text { statistic }\end{array}$ & $p$-value & $\begin{array}{c}\text { Decision } \\
(\alpha=0.05)\end{array}$ \\
\hline $\begin{array}{c}\text { Cluster-1 } \\
\left(n_{1}=17\right)\end{array}$ & Cluster-2 & 21373.316 & 6464.06 & 0.000 & $\mathrm{H}_{1}$ \\
\cline { 2 - 6 } & Cluster-3 & 32846.255 & 10140.41 & 0.000 & $\mathrm{H}_{1}$ \\
\hline $\begin{array}{c}\text { Cluster-2 } \\
\left(n_{2}=15\right)\end{array}$ & Cluster-1 & -21373.316 & 6464.06 & 0.000 & $\mathrm{H}_{1}$ \\
\cline { 2 - 6 } $\begin{array}{c}\text { Cluster-3 } \\
\left(n_{3}=4\right)\end{array}$ & Cluster-3 & 11472.939 & 10268.37 & 0.030 & $\mathrm{H}_{1}$ \\
\cline { 2 - 6 } & Cluster-1 & -32846.255 & 10140.41 & 0.000 & $\mathrm{H}_{1}$ \\
\hline \hline
\end{tabular}

Source: Authors' calculations (IBM SPSS Statistics 20.0)

Figure 7: Mean diagram of GDP per capita for extracted clusters

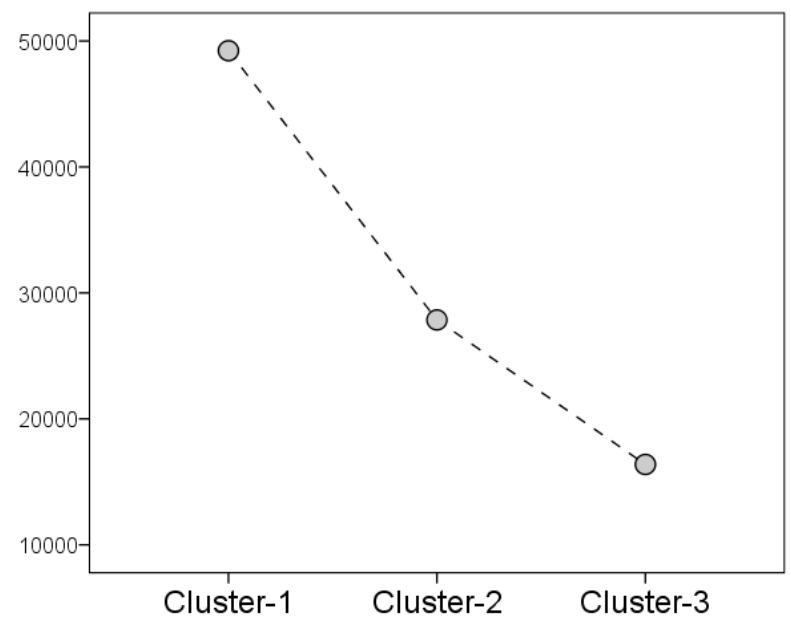

Source: Authors' representation (IBM SPSS Statistics 20.0) 
Finally, ANOVA results are complemented by a graphical representation of average values of the dependent variable by selected categories of the independent variable - level of ICT development (Figure 7).

\section{Interpretation of the research results}

Starting from the presented classification of analyzed European countries within the formed clusters according to the ICT development level (Table 4 and Figure 8) in the structure of Cluster-1 (i.e. high level of ICT development), the presence of Western European countries is dominant, particularly EU countries that gained their membership in the period before 2000 and observed non-EU Western European countries, including Estonia and Cyprus. This CA outcome is quite expected, since these countries are also the best ranked countries according to the total value of the composite IDI index in 2017 (ITU, 2017), which confirmed the logical justification and practical validity of the presented classification.

Figure 8: Cartographic presentation of the classification of selected European countries according to the level of ICT development

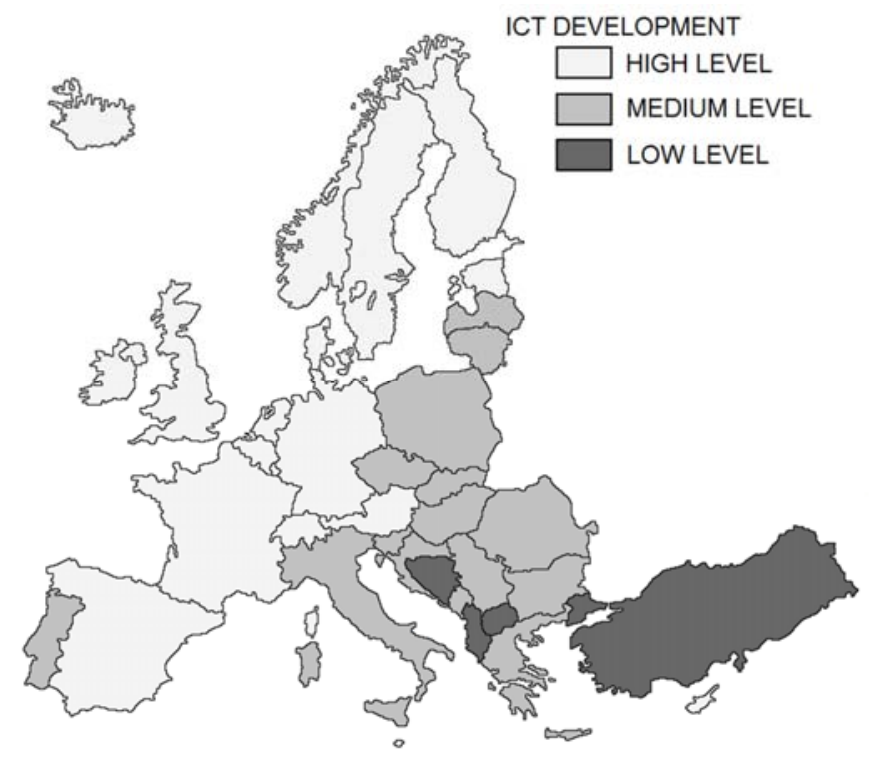

Source: Authors' representation

On the other hand, within the cluster of countries with a medium level of ICT development, in addition to a couple of "old" EU members, there are mostly countries that joined the EU during the last waves of enlargement after 2000. Serbia and [MNE], as candidate countries for EU membership, belong to this cluster as well. Other candidate countries [TUR, MKD, ALB] and [BIH] as a 
potential candidate for EU membership belong to the group of the worst positioned European countries, not just according to the results of the classification presented in this paper but the ITU's "Measuring the Information Society Report 2017" (ITU, 2017) as well. In addition, Zoroja \& Pejić-Bach (2016) presented very similar results of grouping the selected 32 European countries according to the achieved level of development of ICT sector, taking into account certain deviations observed due to different spatial and temporal coverage of data and different ICT indicators.

According to the previously mentioned ITU's Report (ITU, 2017), Serbia is better positioned, according to the value of the ICT Development Index, not only in comparison with the countries within the Cluster-3, but also in relation to [ROU] and $[\mathrm{MNE}]$. A comparative overview of selected descriptive measures' values calculated for individual sub-indices of the IDI index at the level of extracted three clusters and corresponding values for Serbia (Table 8), unequivocally confirms this statement. More precisely, observed in the context of analyzed sub-indices, Serbia is characterized by values that are mostly above the maximum values determined for Cluster-3, and mostly close to average and above minimum values in Cluster-2 to which it belongs.

Table 8: Comparative overview of average, min and max values of individual IDI sub-indices per clusters and corresponding values for Serbia

\begin{tabular}{|c|c|c|c|c|c|c|c|c|c||}
\hline \multirow{2}{*}{ Cluster } & \multicolumn{3}{|c|}{ ICT Access } & \multicolumn{3}{c|}{ ICT Use } & \multicolumn{3}{c||}{ ICT Skills } \\
\cline { 2 - 10 } & mean & Min & Max & mean & min & max & mean & min & max \\
\hline 1 & 8.51 & 7.35 & 9.54 & 8.03 & 7.16 & 8.94 & 8.26 & 6.65 & 8.87 \\
\hline 2 & 7.39 & 6.83 & 7.91 & 6.09 & 5.38 & 6.67 & 8.01 & 7.25 & 9.00 \\
\hline 3 & 5.90 & 4.80 & 6.66 & 4.80 & 4.42 & 5.36 & 6.87 & 6.03 & 7.97 \\
\hline Serbia & 7.20 & \multicolumn{9}{|c|}{5.54} & 7.57 \\
\hline
\end{tabular}

Source: Authors' calculations (IBM SPSS Statistics 20.0)

Regarding the countries' level of economic development and ANOVA results, in the literature mainly emphasized, the confirmation of direct interdependence between the level of ICT and economic development, measured by the GDP per capita, for analyzed countries, is not surprising. More precisely, in accordance with the results of analysis aimed at determining the level of economic development of EU member states, candidates and potential candidates for EU membership, observed from the aspect of average values of GDP per capita (PPP US \$) and unemployment rate for the period 2011-2015, presented in Lovrić \& Stamenković (2016), the identified members of the cluster of high level of ICT development represent also the most economically developed European countries, while Cluster3 mainly includes European developing countries (mainly candidate countries and potential candidates for EU membership), which are characterized by a significantly lower average value of GDP per capita in 2017 compared to the comparative average of the previous two clusters (Table 9). 
Table 9: Comparative overview of average, min and max values of GDP per capita for individual clusters and corresponding values for Serbia in 2017

\begin{tabular}{||c|c|c|c||}
\hline \multirow{2}{*}{ Clusters } & \multicolumn{3}{|c|}{ GDP per capita (PPP US \$) } \\
\cline { 2 - 4 } & Mean & Minimum & Maximum \\
\hline 1 & 52560.56 & $31473.25[\mathrm{EST}]$ & $109191.78[\mathrm{LUX}]$ \\
\hline 2 & 27855.99 & $15163.70[\mathrm{SRB}]$ & $37970.50[$ ITA] \\
\hline 3 & 16383.05 & $11404.13[\mathrm{BIH}]$ & $26453.47[$ TUR] \\
\hline
\end{tabular}

Source: Authors' calculations (IBM SPSS Statistics 20.0)

In contrast to the relatively good and favourable position of Serbia acquired in the classification based on the development of ICT sector, observed in the context of achieved level of economic development, its unfavourable position is clearly noticeable, since it is characterized by the lowest value of GDP per capita within Cluster-2, which is also below the average value determined for the countries within Cluster-3.

\section{Conclusion}

In accordance with the defined subject and objectives of the research, in this paper, a statistical analysis aimed at examining the interdependence of the level of economic and ICT development on the example of selected 37 European countries (EU member states, candidates and potential candidates for membership, as well as Western European countries that are not part of the EU) was conducted, based on the combined application of cluster analysis and one-factor analysis of variance. Based on the presented research results, it is possible to formulate the following concluding statements:

- The obtained classification of selected countries, performed on the basis of representative values of three constitutive components (i.e. sub-indices) of the composite ICT Development Index (namely: ICT Access, ICT Use and ICT Skills sub-index) confirms the presence of "digital division" among the observed European countries, since the solution that includes three clusters is singled out as an optimal. The distribution of European countries within the formed clusters according to the achieved level of ICT development reveals that the structure of Cluster-1 characterized by a high level of ICT development is predominantly composed of Western European and EU countries that gained their membership in the period before 2000 and observed non-EU Western European countries, including Estonia and Cyprus. Within the cluster of countries with a medium level of ICT development, in addition to the "old" EU members, there are mostly countries that joined the European Union during the last waves of enlargement after 2000. Serbia and Montenegro, as candidate countries for EU membership, are classified in this cluster as well. Other candidate countries, Northern Macedonia, 
Albania, Turkey, and Bosnia and Herzegovina, as a potential candidate for EU membership, belong to the group of the worst positioned European countries, regarding the achieved level of ICT development in 2017. These outcomes of the applied classification methodology are generally expected and fully consistent with the rankings of the observed countries based on the corresponding values of the IDI index in the ITU's "Measuring the Information Society Report" for year 2017.

- In the context of the research problem, the application of ANOVA analysis enabled an empirical verification of the presence of statistically significant differences in terms of average values of GDP per capita (used as an indicator of the level of economic development) between all pairs of groups of countries separated on the basis of achieved level of ICT development. More precisely, the results reveal that European countries with a high level of ICT development greatly differ statistically from European countries with medium and low level of ICT development, in terms of the average value of GDP per capita. An identical conclusion can be formulated when it comes to the comparison of clusters of the countries that are characterized by medium and low levels of ICT development. In fact, through a specific combination of multivariate and univariate statistical methods, the existence of the relationship between the degree of economic and ICT development, extensively emphasized in the literature, has been confirmed at the level of the observed European countries.

- According to the ITU's "Measuring the Information Society Report" for year 2017, Serbia is a better positioned country in terms of the value of the ICT Development Index not only in comparison with the countries within Cluster-3, but also in relation to Romania and Montenegro within Cluster-2. More precisely, viewed from the perspective of the values of the analyzed sub-indices, Serbia is characterized by values that are mostly above the maximum values identified for Cluster-3, and mostly close to the average values and above the minimum values determined for Cluster- 2 to which it belongs. In contrast to the relatively good and favourable position of Serbia in the classification conducted according to the characteristics of the ICT sector, observed in the context of achieved level of economic development, its extremely unfavourable position is clearly visible, since it is characterized by the lowest value of GDP per capita within Cluster-2, which is also below the average value determined for Cluster-3.

The obtained research results can serve as a suitable basis for comparing the situations identified in different time moments and analysis of changes (progress or deterioration) of the observed countries' positions. In addition, the examination of statistical significance of the impact and its intensity for individual ICT indicators on the values of economic development indicators, followed by the expansion of the spatial and temporal coverage of data, may represent the directions of future research efforts. 


\section{References}

Aly, H. (2020). Digital transformation, development and productivity in developing countries: is artificial intelligence a curse or a blessing? Review of Economics and Political Science. doi:10.1108/REPS-11-2019-0145

Biagi, F. (2013). ICT and Productivity: A Review of the Literature. Digital Economy Working Paper, No. 2013/09. Luxembourg: Publication Office of the EU.

Chen, D.H.C., \& Dahlman, C.J. (2006). The knowledge economy, the KAM methodology and World Bank operations. Washington, DC: World Bank.

Đorđević, V., Lepojević, V. \& Janković-Milić, V. (2011). Primena statističkih metoda u istraživanju tržišta. Niš: Ekonomski fakultet Univerziteta u Nišu.

Farhadi, M., Ismail, R. \& Fooladi, M. (2012). Information and Communication Technology Use and Economic Growth. PLOS ONE, 7(11), doi: 10.1371/journal.pone.0048903

Görkey Aydınoğlu, S. \& Yalkı Berker, I. (2016). The Comparative Development of ICT in BRICS: A Cluster Analysis. The Journal of Knowledge Economy \& Knowledge Management, XI (Spring), 17-28.

Guzel, S., Murat, D. \& Inam, B. (2016). ICT in Emerging Countries and Turkey: Cluster Analysis Approach. Research Journal of Public Finance, 2 (2), 13-31.

Hogan, T. (2011). An Overview of the Knowledge Economy, with a focus on Arizona. A report from the Productivity and Prosperity Project $\left(\mathrm{P}^{3}\right)$, USA, Arizona: W.P. Carey School of Business, Arizona State University.

International Telecommunication Union (2009). Measuring the Information Society, the ICT Development Index. Geneva: ITU.

International Telecommunication Union (2017). Measuring the Information Society Report 2017. Geneva Switzerland: ITU.

Izenman, A.J. (2008). Modern Multivariate Statistical Techniques. New York: Springer Science+Business Media, LLC.

Krstić, B. \& Džunić, M. (2013). Ekonomija znanja i konkurentnost zemalja Zapadnog Balkana u uslovima svetske ekonomske krize. Teme, XXXVII (1), 141-162.

Lovrić, M. \& Stamenković, M. (2016). Analiza pokazatelja razvijenosti privrede Republike Srbije i zemalja u okruženju. U: Marinković, V., Janjić, V. \& Mićić, V. (Eds), Unapređenje konkurentnosti privrede Republike Srbije (str. 479-491). Kragujevac: Ekonomski fakultet Univerziteta u Kragujevcu.

Majeed, M. T. \& Ayub, T. (2018). Information and communication technology (ICT) and economic growth nexus: A comparative global analysis. Pakistan Journal of Commerce and Social Sciences, 12 (2), 443-476.

Mefteh, H. \& Benhassen, L. (2015). Impact of Information Technology and Communication on Economic Growth. International Journal of Economics, Finance and Management, 4 (2), 90-98.

Mitrović, Đ. \& Manić, E. (2019). Industrija informaciono-komunikacionih tehnologija u Centralnoj i Istočnoj Evropi: razvoj i klasifikacija zemalja. U: Jakšić, M. (Ed.), Perspektive održivog makroekonomskog razvoja Republike Srbije, (pp. 317-332). Beograd: Ekonomski fakultet Univerziteta u Beogradu.

Niebel, T. (2014). ICT and Economic Growth - Comparing Developing, Emerging and Developed Countries. Discussion Paper No. 14-117, Mannheim: Centre for European Economic Research. [http://ftp.zew.de/pub/zew-docs/dp/dp14117.pdf] 
Rousseeuw, P.J. (1987). Silhouettes: a graphical aid to the interpretation and validation of cluster analysis. Journal of Computational and Applied Mathematics, 20, 53-65.

Soldić Aleksić, J. \& Stankić, R. (2016). A Comparative Analysis of Serbia and the EU Member States in the Context of Networked Readiness Index Values. Economic Annals. LX (206), 45-86.

Souter, D. (2004). ICTs and Economic Growth in Developing Countries. Paris: OECD. [http://www.oecd.org/dataoecd/15/54/34663175.pdf]

Stankić, R., Jovanović Gavrilović, B. \& Soldić Aleksić, J. (2018). Information and Communication Technologies in Education as a Stimulans to Economic Development. Economic Horizons, 20 (1), 59-71.

Statistics Netherlands (2015). ICT \& Economic Growth. The Hague: Statistics Netherlands.

Toader, E., Firtescu, B.N., Roman, A. \& Anton, S.G. (2018). Impact of Information and Communication Technology Infrastructure on Economic Growth: An Empirical Assessment for the EU Countries. Sustainability, 10 (10), 1-22.

Van Reenen, J., Bloom, N., Draca, M., Kretschmer, T., Sadun, R., Overman, H. \& Schankerman, M. (2010). The Economic Impact of ICT (Final Report No. 2007 / 0020) London: Centre for Economic Performance.

Vu K., Hanafizadeh P. \& Bohlin E. (2020). ICT as a driver of economic growth: A survey of the literature and directions for future research. Telecommunications Polic, 44 (2), doi: 10.1016/j.telpol.2020.101922

World Bank Institute (2008). Measuring knowledge in the world's economies - Knowledge Assesment Methodology and Knowledge Economy Index. Knowledge for development program. [http://web.worldbank.org/archive/website01030/WEB/IMAGES/KAM_V4.PDF]

Zoroja, J. \& Pejić Bach, M. (2016). Impact of Information and Communication Technology to the Competitiveness of European Countries-Cluster Analysis Approach. Journal of Theoretical and Applied Electronic Commerce Research , 11(1). dx.doi:10.4067/S0718-18762016000100001

\section{Data Sources:}

International Monetary Fond, electronic database [http://www.imf.org].

International Telecommunication Union, electronic database [http://www.itu.int]. 


\section{STATISTIČKA ANALIZA MEĐUZAVISNOSTI IKT-A I EKONOMSKE RAZVIJENOSTI ODABRANIH EVROPSKIH DRZ̆AVA}

Rezime: Fokusiranje istraživačkog interesa na ispitivanje međuzavisnosti informacione i ekonomske razvijenosti proizlazi iz činjenice da su, tokom poslednjih decenija, IKT postale pokretač i dominantni faktor u generisanju ekonomskog i socijalnog prosperiteta razvijenih i zemalja u razvoju. Suštinski, IKT ekspanzija je stimulans za ekonomski rast i obrnuto, širenje IKT-a može se smatrati rezultatom ekonomskog rasta. U cilju empirijske provere posmatrane međuzavisnosti, na primeru odabranih 37 država Evrope, sprovedna je dvoetapna statistička analiza, zasnovana na kombinovanoj primeni analize grupisanja i jednofaktorske analize varijanse. Konkretno, korišćenjem podataka iz 2017. godine, izvršeno je: (a) formiranje grupa implementacijom analize grupisanja na bazi tri strukturne komponente IDI indeksa; i (b) primenom ANOVA metoda i korišćenjem vrednosti BDP per capita, ispitivanje pretpostavke o postojanju statistički značajnih razlika u pogledu dostignutog stepena ekonomske razvijenosti između formiranih grupa država različitog stepena IKT razvijenosti. Dobijeni rezultati sugerišu izdvajanje tri grupe zemalja u kontekstu korišcenih IKT pokazatelja i prihvatanje definisane hipoteze. Srbija je klasifikovana unutar grupe srednje IKT razvijenosti i odlikuje se vrednošću BDP per capita koja je znatno ispod proseka grupe, što ukazuje na prostor i potrebu za poboljšanjem u IKT polju.

Ključne reči: statistička analiza, klaster analiza, ANOVA, IKT razvijenost, ekonomska razvijenost, odabrane evropske države

\section{Authors' biographies}

Milan Stamenković, PhD, is an Assistant Professor at the Faculty of Economics, University of Kragujevac, and a member of the Department of informatics and quantitative methods (teaching courses: Fundamentals of Statistics and Applied Statistics). His research interests are related to topics in the field of applied statistical analysis in economics.

Marina Milanović, $\mathrm{PhD}$, is an Assistant Professor at the Faculty of Economics, University of Kragujevac, and a member of the Department of informatics and quantitative methods (teaching courses: Fundamentals of Statistics and Applied Statistics). Her research interests are related to topics in the field of applied statistical analysis in economics.

Dragana Rejman Petrović, PhD, is an Assistant Professor at the Faculty of Economics, University of Kragujevac, and a member of the Department of informatics and quantitative methods (teaching courses: Information Systems and Management Information Systems). Her research interests are related to topics in the field of business information systems 